\title{
As origens e o significado do regime republicano: interpretações em disputa
}

Rodrigo da Rosa Bordignon*

Resumo: presente artigo tem por objeto o problema das relaçôes entre agentes sociais, posiçôes políticas e os modos de significação dos acontecimentos que marcaram a transição entre regimes políticos no Brasil de fins do XIX. A partir de um conjunto de produçôes simbólicas situadas, a análise centra-se no exame dos sentidos atribuídos e das explicaçóes acionadas para a queda do regime monárquico e ascensão do republicano. O objetivo geral é apreender as representaçôes que embasam os modos legítimos de reivindicação de acesso aos cargos e às oportunidades abertas pelo novo regime em instalação.

Palavras-chave: Monarquia. República. Princípios de Legitimação.

\section{Introduçáo}

A narrativa e interpretação dos acontecimentos que desembocaram na proclamação da República, constituíram o objeto central das lutas pelo sentido das mudanças em curso, nas quais os contemporâneos se engajaram firmemente seja em nome do novo regime em implantação, seja na defesa das características do Império. De modo geral, tratam-se de textos que expóem os pontos de vista das posiçôes em disputa, sintetizadas na oposição geral entre "republicanos" e "monarquistas". Em resumo, o que está em jogo nos relatos e nas produçôes simbólicas desse período é o esforço em "[...] defender ou

\footnotetext{
* Professor do Departamento de Ciência Política da Universidade Federal do Rio Grande do Sul - UFRGS. Doutor em Ciência Política pela mesma instituição com estágio de Doutorado Sanduíche na École Normale Supérieure de Paris - França. E-mail: rrbordignon@hotmail.com.
} 
atacar o que veio depois, isto é, a República inaugurada em 1889" (STEIN, 1964, p. 101). Dito isso, cabe esclarecer que o objetivo do presente artigo não está em retomar a produçáo historiográfica sobre o período imperial e republicano (STEIN, 1964; COSTA, 1999; FERREIRA; GOMES, 1989), mas de tomar para análise o conjunto de depoimentos e de posicionamentos que se pretendem como subsídios para a "história" ou, ao contrário, como "análises dos fatos". Como narrativas nas quais os produtores dos discursos estavam diretamente envolvidos, interessa o conjunto de representaçóes que englobam a reconstrução do passado e que comportam a síntese das características do presente, elaborada em um contexto específico de lutas pelo sentido dos acontecimentos e/ou suas causas, nas quais os produtores simbólicos estão diretamente envolvidos. Nesse sentido, as apreciaçóes e os testemunhos sobre o período histórico vivido e/ou sobre os acontecimentos passados variam de acordo com: 1 . os efeitos biográficos da troca de regime político; 2 . o alinhamento ideológico ou o "adesismo" às diferentes "causas" em confronto.

Os pilares que balizam as tomadas de posição e as representaçôes acerca dos diferentes regimes, e suas respectivas lógicas de funcionamento, modos de acesso ao poder e discursos justificadores, configuram a "fisionomia do tempo". Além disso, explicitam as posiçóes a partir das quais se pode falar com autoridade sobre o mundo social e suas divisóes. Nesses confrontos, as lutas pela definição da "política" estão travestidas pelos esforços de associação entre regime político e princípios de excelência e hierarquizaçáo social, assim como pelos próprios modos de legitimação do exercício do poder. $\mathrm{Na}$ concorrência pela imposição da verdade sobre o período em curso, definem-se tanto os significados históricos atribuídos aos grupos que tomaram parte no processo quanto as diferenças entre os regimes políticos em disputa. A visão dos contemporâneos sobre as hierarquias e os princípios de excelência social fundamentam os diferentes investimentos e reconversóes, compondo a simbologia da excelência que associa, analogamente, determinados períodos históricos aos atributos formalmente exigidos para ascensão social ou acesso aos cargos mais rentáveis (simbólica e economicamente). $\mathrm{O}$ foco das oposiçóes centra-se na interpretação dada aos fatos e suas consequências, cujos temas centrais em debate são os efeitos e/ou as 
definiçôes do "abolicionismo", do "poder pessoal", do "movimento republicano", da "organização social”, da "classe militar" e outras classes sociais para a estrutura de poder e a queda do Império.

De um modo bastante direto, as visóes apresentadas para o processo histórico em curso estão divididas entre "vencedores" e "perdedores", ou seja, entre aqueles que galgaram postos e vantagens com a instauraçáo do novo regime, e aqueles que foram atingidos pelas "derrubadas" decorrentes das mudanças políticas do país. Igualmente, elas representam a leitura prática da realidade em transformação e as condições de reconversão em direção às posições mais vantajosas, as quais se definem a partir das expectativas inscritas no horizonte dos possíveis. Mesmo para aqueles que conseguiram reconverter seus recursos para outros domínios de atividade, ou os que mantiveram suas posiçóes previamente conquistadas através da adesão aos novos grupos no poder, a República representou um aumento relativo na competição pelos postos e a ascensão de novos princípios de hierarquização, cujos efeitos foram sentidos de modos distintos nas trajetórias. No entanto, os efeitos de trajetória para muitos dos membros desse último grupo são bastante relativos, particularmente pelos recursos prévios sustentados, o que lhes permitiu um variado leque de possibilidades de reconversão de investimentos.

\section{A República é o que o Império não foi}

Dentre os autores e as posiçóes político-ideológicas reivindicadas, duas obras marcam de modo mais direto os embates entre perspectivas, modos de definição dos regimes e suas causas. Sáo casos exemplares, pois encerram, ao mesmo tempo, concepçóes distintas sobre o fenômeno histórico em questão, e decorrem de efeitos de trajetória que atingem seus autores, as quais são representativas dos confrontos entre origens sociais, carreiras, recursos acumulados e/ou herdados e o contexto de instauração da República. Além disso, há entre elas uma oposição explícita e declarada, ao estilo publi-cação-resposta. De um lado, encontra-se o livro de Afonso Censo de Assis Figueiredo Junior, O Imperador no Exílio (1950 [1893]); de outro, o de José Felício Buarque de Macedo, Origens Republicanas (1894). De modo 
bastante específico, trata-se de um confronto pela verdade dos fatos, pelos significados e pelos modos de exercício do poder nos dois regimes. As próprias obras e seus autores são enquadradas nos respectivos momentos da história política do país, uma delas correspondendo à "tradição", a outra, à "modernidade". Nas palavras de seu crítico, o livro de Afonso Celso é produto do trabalho de um "filho de antigos servidores da família imperial", sendo "desenvolvido num círculo de rotina e de conveniências", resultado das "condiçôes de hereditariedade" que lhe impeliram a escrever tais impressóes. Em contraposição, José Felício Buarque (1894, p. 2-6) enquadra seu próprio escrito em uma perspectiva "cientificista", cuja polêmica é deixada de lado em nome da adoção de uma postura objetiva e factual da história, dispondo-se a contrapor aos "desígnios da polêmica", um sistema de conceitos amparados pelo "critério de análise e comparação dos fatos". A oposição reivindicada por Felício Buarque entre a Monarquia e a República, cola-se ao sistema de homologias significantes que operam pela oposição entre "tradicional" e "moderno", "favoritismo" e "impessoalidade", "conservadorismo" e "progressismo", "imobilidade" e "mobilidade", "herança" e "competência", cujo resultante é a configuração de um sistema de classificaçóes e suas consequências para a modificação dos princípios de hierarquização social.

No contexto de ascensão do regime republicano, o conjunto de opúsculos e escritos que surgem com pretensôes de "historiar" os fatos que levaram à queda da Monarquia, e de definir os princípios regentes do novo regime, fazem parte das estratégias de significação dos acontecimentos e de coroamento de seus "heróis", além de representar o "adesismo" de antigos monarquistas, então travestidos de republicanos. A crítica dirigida pelo Visconde de Ouro Preto (1891, p. 161), último presidente do Conselho de Ministros do Império, aos "historiadores da República", coloca de modo objetivo a centralidade das disputas pelo significado dos acontecimentos e das causas da queda do Império e suas instituiçóes. Segundo o autor, a "pressa" em publicar determinados "folhetos" - refere-se ao livro de Cristiano Ottoni -, é decorrente dos interesses em demonstrar ao "governo provisório" a disponibilidade em relação ao regime em instauração. As "memórias íntimas", com ligeiros "retoques", publicadas por Cristiano Ottoni em 1890 , indicam o caráter conjuntural das adesóes e da proclamação 
de princípios ideológicos, fenômeno característico das disputas e dos confrontos faccionais. É exemplar, neste caso, o próprio autor referir que sua adesão ao manifesto republicano de 1870 foi algo conjuntural, decorrente de uma situação de injunção em que a não assinatura poderia representar um "cotejo a Monarquia" e um afastamento da "sociedade" (OTTONI, 1890, p. 75). Igualmente, a justificativa de Ottoni para seu afastamento do Clube formado pela dissidência do Partido Liberal, acompanhada de sua negação em ser da "militância política" republicana, são ilustrativos da postura de não ruptura com o regime instituído, em grande parte justificada pelas condiçóes históricas específicas: o Brasil não estava pronto para a República, era necessário realizar primeiro outras reformas e aguardar a evolução natural (OTTONI, 1890, p. 73-75). Ao mesmo tempo em que ocorrem transiçóes simultâneas entre concepçóes de sociedade e de política, há um esforço contínuo em inscrever as ideias republicanas na "tradição", principalmente através da reivindicação de fatos históricos - tais como a Inconfidência Mineira (1789) - como manifestaçôes legítimas de ideais republicanos historicamente manifestos ou latentes na "sociedade". O argumento central é que tais ideais foram sufocados pelas instituiçóes monárquicas, pela permanência da escravidáo e pelo estado cultural do país. Nesses esforços de significação do regime instaurado pós-1889, as estratégias "teleológico-políticas" (BOURDIEU, 2007, p. 79-80), características de períodos nos quais as fronteiras de definição ainda estáo incertas, são constantemente acionadas em diversas tomadas de posição, em grande parte associadas a ideais tomados como correlatos ao republicanismo, notadamente o "abolicionismo" e as chamadas "aspiraçôes democráticas" (OTTONI, 1890; BUARQUE, 1894; SUETÔNIO, 1896; AZEVEDO, 1894).

De modo bastante amplo, os eixos em torno dos quais se estruturam os debates sobre a queda do regime monárquico, encontram-se esquematizados na obra elaborada por Cristiano Ottoni em 1890, sendo os que seguem: 1. a abolição da escravidão doméstica; 2. a evolução natural da ideia democrática; 3 . as queixas e o descontentamento da oficialidade do exército; 4 . o descrédito que a política imperial lançou sobre a instituição monárquica (OTTONI, 1890, p. 3). O conjunto de temas elencados por Ottoni, de modo mais ou menos direto, compóem a produção simbólica dos anos iniciais da 
República e balizam as disputas pelos sentidos atribuídos a eles, e consequentemente, seus efeitos para a transição entre regimes. De modo geral, os pontos de controvérsia são bastante dispersos, embora variem com base no esforço de definição do que significa cada regime, de seus princípios de hierarquização e dos modos através dos quais as mudanças são operadas. Um dos pontos centrais de inscrição das tomadas de posição é a oposição entre as filosofias sociais e da história que fundamentam as produçóes simbólicas, assim como suas relaçóes com os modelos de organização política e social em disputa. O grande eixo que divide as tomadas de posição está no confronto entre a "pequena política" e a "política com P grande" (NABUCO, 1900 , p. 33), entre a "política de alfinetes" e a "política de princípios" (SUETÔNIO, 1896, p. 91). Nesse esquema de enquadramento, o Império seria a política personalista e "sentimentalista", enquanto a República seria a política dos ideais universais, dos princípios impessoais e técnicos de organização social e de administração do estado.

É consenso entre os contemporâneos que a causa "abolicionista" se apresentou como uma injunção histórica, princípio definidor de tomadas de posição, produtora de um universo crescente de militantes e adeptos. Seus efeitos estáo expressos em distintos relatos memorialísticos, particularmente por sua centralidade nos processos de socialização estudantil (NABUCO, 1900; AFONSO CELSO, 1998 [1898]; CAMPOS SALLES, 1908). Inscrita em um período histórico específico, insere-se no conjunto sucessivo de reivindicaçôes "liberais" que se avolumam pós-cisão do Partido Liberal, em 1868. A radicalização desta ruptura se dá com a adesão à causa republicana e o lançamento do Manifesto Republicano, em 1870. No quadro histórico de sua emergência, o "abolicionismo" e o "republicanismo" constituem-se como causas tidas e proclamadas como "modernas", como reformas "civilizatórias", , conquistando adesôes significativas de parcelas de profissionais liberais e estudantes de ensino secundário e superior, grupos predominantes na condução do movimento propagandista pós- $1870^{3}$. No entanto, prevaleceu a ideia abolicionista como carro-chefe das reformas exigidas, enquanto o republicanismo surgiu quase como extensão de reivindicaçóes ligadas à primeira, ganhando maior força a partir de meados da década de 1880. Outro fator decisivamente associado à ascensão da ideia republicana está associado 
aos constantes conflitos entre as "elites locais" e o "poder central", particularmente no que tange à frequente intervenção do segundo nos "negócios" do primeiro. Nesse quadro, as reformas reivindicadas compreendem a independência do "poder local" frente à intervenção da Coroa (TAVARES BASTOS, 1870), cujo princípio básico era a exigência da eletividade dos cargos de presidente de província ${ }^{4}$, e as consequentes possibilidades de controle da distribuição local do poder.

Constituindo-se como um universo de sociabilidade, o engajamento na causa abolicionista representou, nas palavras de Afonso Celso (1998 [1898], p. 56), uma oportunidade para que os "mais medíocres" tirassem proveito da situação, ingressando em círculos sociais anteriormente fechados. Entretanto, mesmo que a dinâmica situacional vinculada ao engajamento em uma causa emergente tornasse possível que os "[...] holofotes recaíssem sobre indivíduos obscuros [...]" (AFONSO CELSO, 1998 [1898], p. 56), as condiçôes e o alcance das carreiras decorrentes dos recursos adquiridos na militância dependiam de outros investimentos, tornando o acesso aos cargos, às publicaçóes e aos universos de socialização previamente hierarquizados. De tal modo, não raro visóes e projetos políticos reformistas relacionam-se diretamente às posiçóes sociais de origem, aos pontos das trajetórias e as condiçóes de reconversáo dos trunfos adquiridos na militância em posiçóes em determinadas esferas de atuação. Nesse confronto, estão expressas as tomadas de posição mais "radicais", encampadas por José do Patrocínio e Quintino Bocaiuva (PATROCÍNIO, 1996; BOCAIÚVA, 1887); ou o discurso de "abolição com preservação da propriedade”, de Joaquim Nabuco (NABUCO, 1900; 2011 [1883]).

A principal decorrência do contexto situacional de "propaganda" foi a aglutinação de militantes de diversos matizes e níveis, o que produziu uma saturação dos mecanismos de arregimentação personalista, causando determinadas rupturas nos modos através dos quais se realizavam os acordos políticos de época. A possibilidade de que um conjunto mais amplo de indivíduos se inserissem na política, particularmente através do jornalismo político e da organização de clubes de socialização, tenciona as discussões em direção a "reforma" dos mecanismos de recrutamento e ao alargamento das oportunidades sociais, criando uma espécie de inflexão nos modos de manutenção $\mathrm{da}$ ordem social vigente. Isso ocorre, particularmente, pelos efeitos 
de descompasso entre as expectativas decorrentes do contexto de reivindicação reformista, e as oportunidades efetivas abertas pelo regime político instaurado no país. A consequência mais geral destes conflitos, é a construção de uma oposição entre os grupos conservadores "assenhorados no poder" e as "classes modernizantes". De fato, as geraçôes que participam das atividades de "propaganda" constituem as principais fileiras daqueles que vão compor a base de questionamento das instituiçóes monárquicas e de seus mecanismos de recrutamento, tencionando as estruturas em nome da ampliação de oportunidades e da modificação dos princípios de hierarquização. Em parte desse período de confronto, imperou o "reformismo" dentro da ordem (ALONSO, 2002), no entanto, como relata Campos Salles (1908), em certo momento, chegou-se a compreensão de que as reformas visadas eram impossíveis dentro da Monarquia, restava uma mudança no regime político.

As interpretações sobre os efeitos do movimento abolicionista para a decadência das instituiçóes monárquicas giram em torno da própria concepçáo das origens e dos efeitos do movimento para a estrutura de poder. Para os defensores do Império, a causa da abolição arregimentara uns poucos adeptos, em sua maioria estudantes, "[...] indivíduos sem nada a perder [...]”, sem a devida compreensáo dos efeitos de tal medida para a "economia" e a ordem social (ANAIS DO SENADO DO IMPÉRIO, 1885). Do lado dos “republicanos”, a abolição representava um passo em direção à modernidade, uma etapa evolutiva da organização social, constituindo-se como uma causa que penetrou em todas as classes da sociedade, arregimentando adeptos em múltiplos segmentos (BUARQUE, 1898, p. 28). O caminhar inevitável da história tornou o fim da escravidão um movimento irreversível, cabendo à Coroa apenas homologá-lo (OTTONI, 1890, p. 63). O geral nessas disputas é a oposição entre uma concepção de "movimento histórico" evolutivo (SALES, 1882), contraposto à noção de uma história feita por seus "heróis", por iniciativas particulares de homens de visão, os quais tendem a trazer o futuro para o presente. É exatamente em tal ponto que incorrem as divergências quanto à origem da abolição e seus efeitos. Para os defensores da Monarquia, a iniciativa destinada a pôr fim ao trabalho escravo fora do Imperador, assim como o decreto de fim da escravidão fora uma ação benevolente, 
encampada por uma instituição que acenava em direção às reformas morais e sociais necessárias à continuidade do regime e da ordem social (PRADO, 2003 [1893]). Nessa perspectiva, o não reconhecimento de tal ato era característico do estado de insubordinação em que se encontrava a "sociedade". Independente do esforço para "frear" os ímpetos reformistas a que se lançou o último gabinete, a "propaganda republicana" aproveitou-se do descontentamento das "classes da lavoura e do comércio", arregimentou novos adeptos e tencionou a deposição do Imperador (VISCONDE DE OURO PRETO, 1891, p. 98). Em suma, o ato fora uma "parada militar", decorrente do aliciamento das forças armadas, as quais "proclamaram a ditadura militar no Brasil, sob o nome de República” (AFONSO CELSO, 1998 [1898], p. 126).

A filosofia da história importada com a ideologia republicana em ascensão na França (WEISZ, 1979), implica uma mudança de foco relativamente aos mecanismos da transformação social. Configurados pelo confronto entre grupos que desejam a conservação do poder e o movimento natural em direção a uma forma mais avançada de organização política e social, os embates fundamentam-se no binômio conservadores/progressistas. De tal modo, na visão dos contemporâneos, o movimento histórico caracteriza-se pela oposição entre o "povo" e as "vistas retardatárias do chefe do poder executivo" (BUARQUE, 1894, p. 27). A atribuição de um caráter ilegítimo ao regime instalado em 1889 é constante, particularmente pela consideração de que sua "[...] origem [é] criminosa [...]" (VISCONDE DE OURO PRETO, 1890, p. 104), feita por uma única classe - “a classe militar" -, em detrimento de todas as demais. A própria lógica de controle da imprensa e de policiamento simbólico nos anos iniciais da República, reforçava as visóes difundidas pelos adeptos do antigo regime, para os quais a questáo constantemente levantada era o caráter ditatorial da República, contraposto à representação de que a "[...] Monarquia era o regime da liberdade [...]", sempre garantida por sua "constituição liberalíssima” (PRADO, 2003 [1893], p. 33).

Contrapondo-se a visão constantemente apregoada de que a República fora feita por e para uma "classe", os "republicanos" reivindicam, ao contrário, que o regime instituído jamais será "privilégio de uma classe" (AZEVEDO, 1894, p. 273), mas sim o resultado da 
ascensão "das camadas populares e da consequente democratização da sociedade", o que fez "estremecer" os alicerces das "instituiçóes régias". Advindo das aspiraçóes decorrentes do avanço das "ciências, artes, indústrias e letras" o regime republicano constitui-se como a consequência lógica de um processo evolutivo, é a "apoteose da era moderna” (BUARQUE, 1894, p. 15). Nesse contexto, o policiamento simbólico do regime em instalaçáo no país nada mais era do que uma forma de proteção do povo contra as "farsas" produzidas por aqueles que ansiavam restaurar o poder (BUARQUE, 1894; OTTONI, 1890). A situação de luta contra os não republicanos e os "adesistas subversivos", instalados no poder para manter as posiçóes do Império e/ou infiltrados nas estruturas do novo regime para desestabilizá-lo, produz um tipo de efeito de esquizofrenia, funcionando como elemento de resoluçáo de desafetos ou de eliminação de concorrentes aos cargos e às posiçóes visadas. Em grande medida, havia uma visão relativamente difundida de que os "neo-republicanos", ou os "republicanos do treze de maio", constituíam um obstáculo à realização das pretensões "democráticas" e "igualitárias" do regime ascendente. Isso deve-se, particularmente, porque tais "grupos” eram formados de "plutocratas" reconvertidos, indivíduos "afeitos a grandes desigualdades sociais", os quais dificilmente hão de considerar como iguais os membros de outras classes ou estratos sociais (OTTONI, 1890, p. 79). No contexto de "condenação das heranças" e das "posiçôes privilegiadas", torna-se ilegítima qualquer referência a pontos de partida considerados como privilegiados, ou seja, que indiquem critérios não universalizáveis. Assim, os trunfos legítimos de serem apresentados para a ocupação de cargos passam a ser as certificaçóes formais de competência - títulos escolares, reconhecimento pelos pares e concursos -, elementos que se tornam centrais nas estratégias de apresentação de títulos e na própria elaboração de dicionários biográficos. Com a formalização dos princípios de hierarquização e excelência, o sentido de distinção social é crescente, principalmente devido às situaçóes nas quais os "antigos senhores" ou seus "rebentos" tinham que "ombrear" com indivíduos de origens adversas ou com ex-escravos (ANAIS DO SENADO DO IMPERIO, 1874). A lógica clubística e faccional é asseverada como estratégia de proteção mútua e de fundação de relaçóes de dependência, garantindo vantagens 
variadas aos partícipes destas redes. No contexto republicano, a concorrência aberta pela multiplicação dos níveis de inserção social e pela complexificação das alianças é fundamental para a compreensão dos mecanismos de diversificação das carreias e das condiçóes de especialização das esferas de atuação.

É contra a concepção de concorrência igualitária que se insurgem os defensores de uma hierarquia social proclamada, mantida por uma espécie de "filantropismo" através do qual os mecanismos de exploração social eram considerados formas de exercício da superioridade e de manutenção da ordem. Dessa forma, ao contrário do regime instalado em 1889, que lança a "multidão infeliz" à sua própria sorte, a Monarquia era "benevolente", fazia da escravidão e da união com a Igreja mecanismos de manutenção da ordem e de proteção social (PRADO, 2003 [1893], p. 78-81). Igualmente, o caráter efêmero, transitório e impessoal da administração dos negócios públicos, apregoado pelo modelo republicano, torna-o irresponsável, um regime incapaz de promover reformas sociais de longo prazo. No conjunto de lutas de definição a que se lançam os partidários dos diferentes regimes, a Monarquia é proclamada por seus adeptos como o período da "segurança" e da "estabilidade", momento de relativa previsibilidade. Enquanto isso, a República é caracterizada por seus defensores como um movimento de todas as classes, um universo de participação aberto a todos aqueles que dispunham de virtudes morais e intelectuais. Tratava-se, portanto, de um regime não afeito aos privilégios de fortuna (BUARQUE, 1894, p. 70-71). A proclamação do mérito como capacidade intelectual - caucionada ou não por títulos escolares -, em contraposição ao mérito "por serviços prestados” (VISCONDE DE OURO PRETO, 1890, p. 137), por "herança", ou por "servilhismo", imperantes durante a Monarquia (BUARQUE, 1894, p. 227; SUETÔNIO, 1896, p. 80; BOCAIÚVA, 1887 , p. 13), é a marca significativa dos escritos republicanos. Nesse quadro, a República diferia do regime precedente exatamente por estar aberta à "ascendência das camadas populares e a consequente democratização da sociedade” (BUARQUE, 1894, p. 15). Em trabalho publicado no ano de 1882, destinado a fundamentar a "[...] conduta do partido republicano [...] mediante uma sistematizaçáo completa dos princípios fundamentais que constituem sua bandeira 
[...]", Alberto Sales (1882, p. IX) apresenta a insuficiência do regime monárquico justamente por sua incapacidade de representar os anseios do "interesse social", fundamentalmente contraditórios frente aos “interesses dinásticos". A base dessa contradição está no crescimento da influência das "classes populares" como forma de evolução contínua das "forças democráticas", as quais tendem a romper com a Monarquia em nome da República, regime responsável por "[...] restabelecer a unidade do interesse social e político” (SALES, 1882, p. 183-184).

O privilégio, em todas as suas relaçóes com a sociedade - tal é, em síntese, a formula social e política do nosso país - privilégio de religião, privilégio de raça, privilégio de sabedoria, privilégio de posição, isto é, toda as distinçóes arbitrárias e odiosas que criam no seio da sociedade civil e política a monstruosa superioridade de um sobre todos ou a de alguns sobre muitos. (MANIFESTO DO PARTIDO REPUBLICANO. In: BRASILIENSE 1878 [1870], p. 62)

O “calcanhar-de-aquiles do Império" estava, portanto, em não permitir que "homens sem fortuna, desajustados de proteçóes eficazes, unicamente escudados na inteligência" (BOCAIUVA [1862] apud ALONSO, 2002, p. 108 pudessem ascender às posiçóes de poder ou dispor de algum destaque em suas respectivas atividades.) $\mathrm{O}$ principal motivo disso estava atrelado ao fato de que todo o "prestígio individual" vinha da Coroa, assim como o outro lado da moeda: o "ostracismo" (NABUCO, 2011 [1883], p. 125). Em grande medida, as críticas dos republicanos aos mecanismos de controle das reputaçôes e do acesso aos cargos por parte do Monarca constituem um dos pilares das disputas entre as características do regime. A crítica assevera-se pela caracterização de que o exercício "pessoal” da política imperial representava a própria “índole” do sistema, transfigurada no "poder moderador” (BOCAIÚVA, 1896, p. IX). De um modo bastante direto, não havia forma de legitimidade que não fosse dependente do controle e reconhecimento por parte da instituiçáo régia e, de modo mais exato, que não passasse pelo crivo do Imperador. Sendo assim, critérios de "afeição pessoal" sobrepunham-se àqueles formalmente instituídos, tornando as "capacidades e virtudes" elementos vazios 
em um sistema de privilégios personalistas (SUETÔNIO, 1896, p. 80). A lógica do favoritismo estava inscrita na própria estrutura de nomeaçôes em cascata, cuja hierarquia era formada pelo Imperador - Presidente do Conselho de Ministros - Ministros - Presidentes de Província. Como todos os cargos públicos eletivos, por cooptação ou mesmo aqueles proclamados como formalmente preenchidos por "concursos", estavam submetidos a este mecanismo de legitimação das pretensóes aos cargos existentes - ou a serem criados -, as possibilidades de objetivação de lógicas de recrutamento e legitimidades próprias e independentes do "poder pessoal" eram muito limitadas, senão impossíveis. Além disso, como tratava-se do próprio sistema formal de atribuiçôes, as instituiçôes monárquicas como um todo viam-se condenadas. As críticas e os confrontos eram asseverados pelas "derrubadas", decorrentes do controle vertical e centralizado dos cargos públicos e do poder de "fazer e desfazer" nomeaçóes e eleiçóes. Na visão dos republicanos, tratava-se de algo que "[...] anulava a soberania nacional [...]” (BOCAIÚVA, 1887, p. 13), notadamente porque o governo representativo era uma "comédia" entregue ao "baraço e cutelo dos cargos policiais, da Guarda Nacional, das fitas e títulos; meios empregados sem a menor cerimônia" na produção dos resultados eleitorais (OTTONI, 1890, p. 11). Com base nisso, o "rodízio" entre os partidos é apontado pelos críticos do Império como o elemento central para o descrédito das instituiçóes monárquicas. Do mesmo modo, o regime garantido por privilégios de nascimento incontestáveis tende a produzir um governo irresponsável.

Nesta lógica, Felício Buarque (1894, p. 231) ensaia expor a "fórmula do regime": "[...] para o Monarca brasileiro só há uma virtude - o servilhismo. Para os homens independentes e sinceros - o ostracismo. Para os lacaios e instrumentos de sua grande política - os títulos e condecorações". A sobreposição entre critérios formais e a preferência pessoal são responsáveis pelo desgaste das instituiçóes monárquicas, em grande medida decorrente da força do "poder pessoal" encarnado nas mãos do Imperador. O controle sobre os mecanismos de consagração (distribuição de sinecuras e condecoraçôes) permitia a construção das reputações, de modo que nenhum brasileiro "[...] se erguesse na consideração de seu país, além de certo nível [...]", regulado pelo "Autocrata" (BUARQUE, 1894, p. 113). 
Em geral, o controle das hierarquias estava associado às "amizades" ou "hostilidades" produzidas por relaçôes personificadas e faccionais. É com relação à posição do Imperador e ao exercício centralizado do poder, potencializado pela instituição do "Poder Moderador", que se define o denominado "poder pessoal", assim como seu contraponto, a "impessoalidade". O controle e o manejo dos homens públicos operados pelo Imperador estáo associados a "todos os males do seu longo reinado" (SUETÔNIO, 1896, p. 103), fundado na concepção de que "[...] só dele pode vir o bem" (OTTONI, 1890, p. 23).

[...] uma vez que o governo, longe de cingir-se única e exclusivamente à manutençáo da ordem, para favorecer a evolução, pelo contrário, concentra em si todas as forças do corpo político, para intervir diretamente no conflito social, as leis gerais da luta pela vida e da seleção natural, em virtude das quais somente podem triunfar os mais fortes e os mais aptos, deixarão infalivelmente de produzir suas legítimas consequências. $\mathrm{O}$ favoritismo, o nepotismo, ou como melhor queiram chamar, farão desaparecer da luta os mais competentes, tanto pela sua inteligência, como pela sua independência, enquanto que o governo, por meio da distribuição ilimitada de condecoraçóes, títulos honoríficos e patentes oficiais criará no país uma classe de amigos e protegidos, tão numerosa e tão bem disciplinada, que a luta se tornará, quando não inteiramente impossível, pelo menos inútil e improfícua. (SALES, 1882, p. 369-370)

É com relação ao quadro pintado pelos críticos da Monarquia que se insurgem as reivindicaçôes de "liberdade" e de "responsabilidade" da administração e do governo, esquemas doutrinários tomados das ideologias vigentes na Europa (ALONSO, 2009). A concepção de que o regime monárquico náo garantia as liberdades individuais, que representava o despotismo, encarnando a decadência administrativa de um poder "dinástico", inquestionável e, por isso, irresponsável e atrelado ao falseamento da "soberania popular", constitui o centro das críticas sintetizadas no Manifesto Republicano (1878 [1870]) ${ }^{5}$, de 1870 . No entanto, mais do que representar a adesão aos princípios ideológicos tidos e proclamados como modernos, a "liberdade" 
reivindicada era a independência dos "chefes locais" frente à Coroa (OLIVEIRA VIANA, 2004 [1925], p. 95). Ou seja, a possibilidade de controle e distribuição de recursos relativamente assegurada pela eletividade dos cargos de presidente de província, ponto de reforma reivindicado e náo aceito pelo último presidente do Conselho de Ministros do Império (OTTONI, 1890, p. 103-104). Nesse esquema, enquadra-se, também, a noçáo de "impessoalidade" contraposta ao modelo de organização do poder político imperial. Significava, de modo amplo, deixar que os conflitos de resolvessem pela força social de seus postulantes, cujos resultados estão associados aos mecanismos formais que garantem o sucesso ao "vencedor", neutralizando o arbitrário e as modalidades práticas concretas através das quais se conquistam as posiçóes e os lucros derivados. De modo mais claro, o centro das críticas circundava o fato que o Imperador náo respeitava os mandados instituídos da Câmara, assim como não respeitava a supremacia dos "votados" nas escolhas baseadas em listas tríplices ou, ainda, operava "derrubadas" constantes com o rodízio dos partidos no poder. Assim, em grande medida, a instauração do regime republicano representou a realização das pretensóes de controle das eleiçôes estaduais pelos chefes locais, cujo efeito é a multiplicação dos níveis de barganha e das modalidades de recrutamento e acesso aos cargos em concorrência. $\mathrm{O}$ confronto entre meios de acesso aos cargos (escolha imperial versus eleiçóes), e a estabilização de seu exercício por meio de mandatos formalizados, garantidos pela instauraçáo da República, vem coroar a ascensão da "legitimidade eleitoral" em oposição aos "arbítrios" do "poder pessoal” vigentes no Império.

\section{Trajetórias e tomadas de posiçáo}

As relaçóes entre trajetórias, posiçóes políticas e carreiras são ilustrativas dos efeitos da instauração do regime republicano, notadamente no que tange às reconversôes para espaços sociais específicos, ou às possibilidades de ascensão e/ou reprodução das posições de poder político. No caso dos monarquistas em pauta, os investimentos são direcionados para o espaço de produçáo cultural enquanto os republicanos tendem a colher os frutos de seu engajamento, ocupando cargos 
eletivos ou na burocracia. As estratégias de reconversão conectamse a um duplo processo: 1. o bloqueio inicial das posiçóes políticas (eletivas ou por cooptaçáo); 2. as disposiçóes em aderir ao regime instituído em 1889, particularmente aqueles anteriormente ligados à Monarquia. Tratam-se de variáveis interconectadas, sendo o adesismo uma alternativa significativamente utilizada como forma de manutenção das chances de atuação na política, e também de ruptura com o bloqueio inicial. No que se refere à sinalização em direção ao novo regime, o trajeto de Cristiano Ottoni é significativo. Contrariamente, o afastamento da política republicana relaciona-se aos casos de Eduardo Prado, Afonso Celso - Visconde de Ouro Preto - e Afonso Celso Junior. Mesmo para aqueles que se afastam da vida pública, como Antônio Ferreira Viana e Afonso Celso - Visconde de Ouro Preto, há uma permanência em termos de atuação e defesa de "causas", notadamente através da imprensa ou, no caso deste último, da participação direta em movimentos pró-restauração monárquica (BONEVIDES; AMARAL, 2002, p. 483-493). Além disso, o confronto entre as produçóes escritas e as posiçóes políticas de ambos remete aos confrontos político-partidários e faccionais. Ferreira Viana fora ministro do gabinete João Alfredo (1888-1889), antecessor daquele organizado e presidido por Ouro Preto. A deposição do gabinete liderado por João Alfredo teria ocorrido por conta da "campanha contra [sua] honra pessoal" (SUETÔNIO, 1896, p. 281), levada a cabo por Ouro Preto, o que atingiu de modo direto Ferreira Viana, então Ministro da Justiça e dos Negócios do Império. 
Rodrigo da Rosa Bordignon

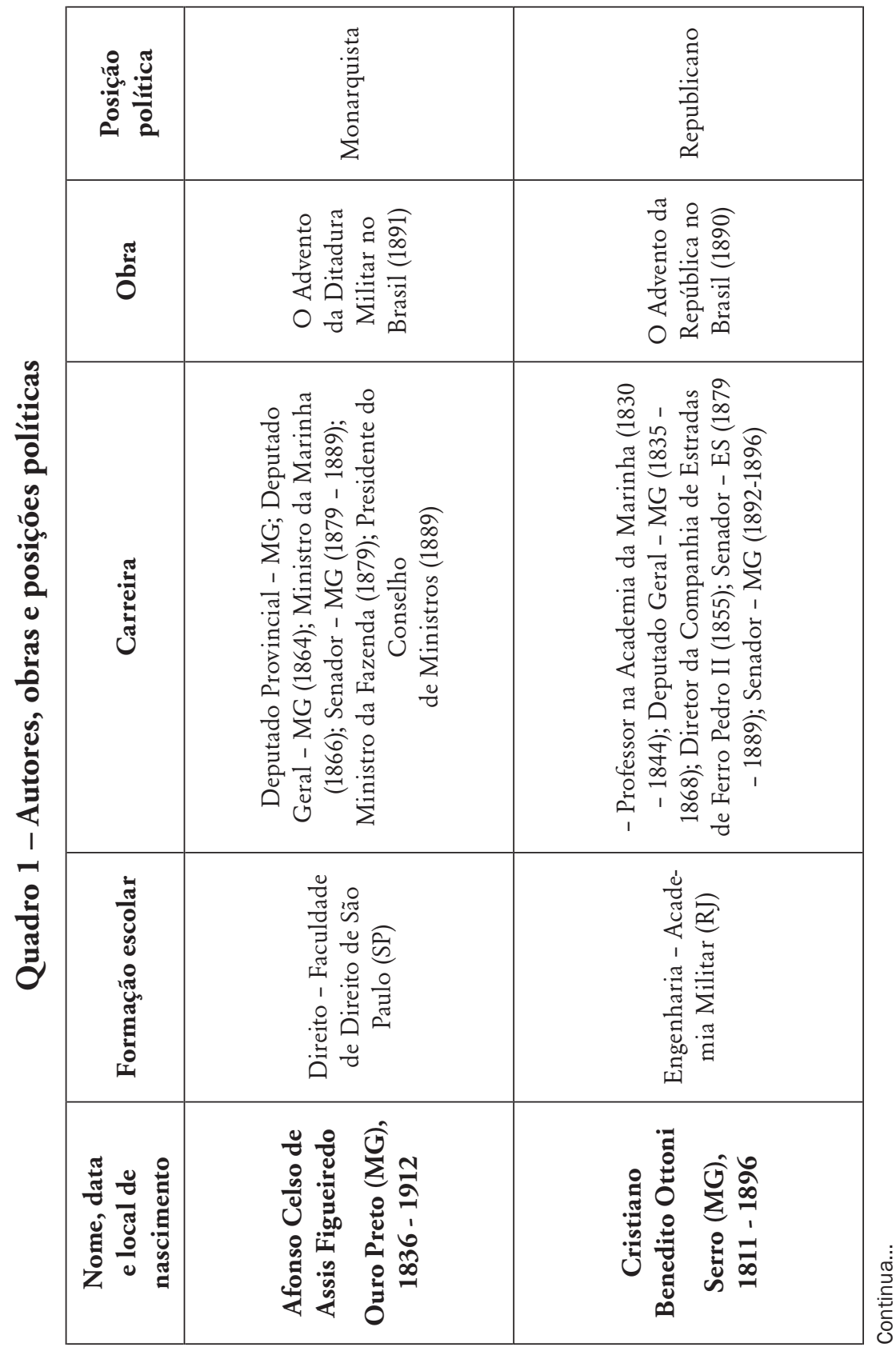

ก

$\vdots$

Anos 90, Porto Alegre, v. 23, n. 43, p. 235-266, jul. 2016 
As origens e o significado...

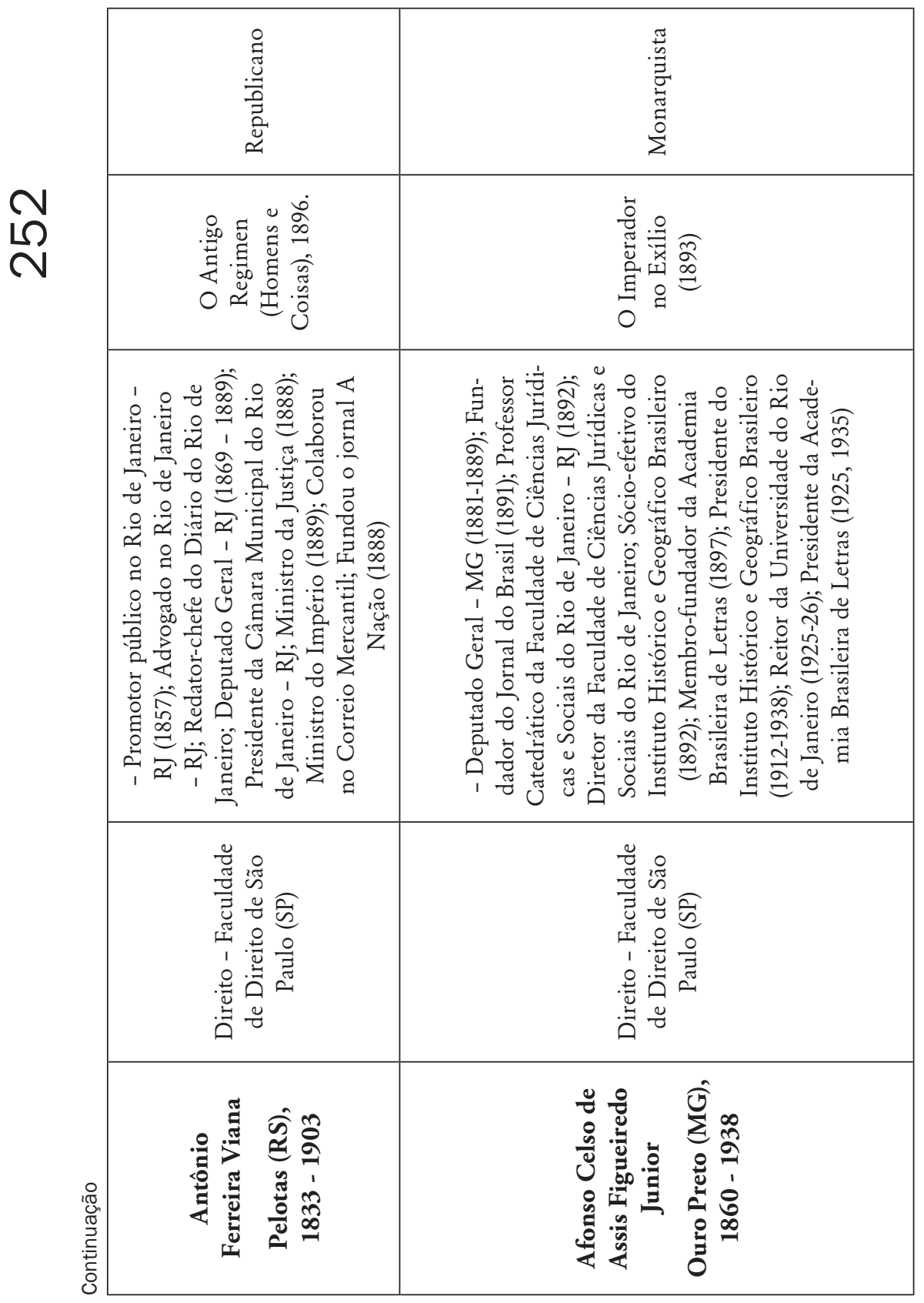

Anos 90, Porto Alegre, v. 23, n. 43, p. 235-266, jul. 2016 
Rodrigo da Rosa Bordignon

\begin{tabular}{|c|c|}
\hline 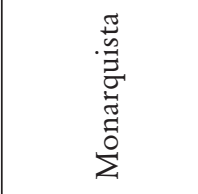 & 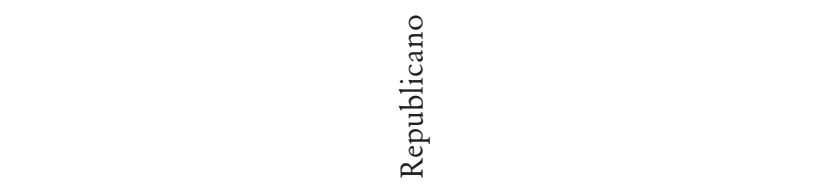 \\
\hline 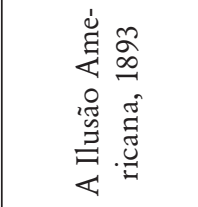 & 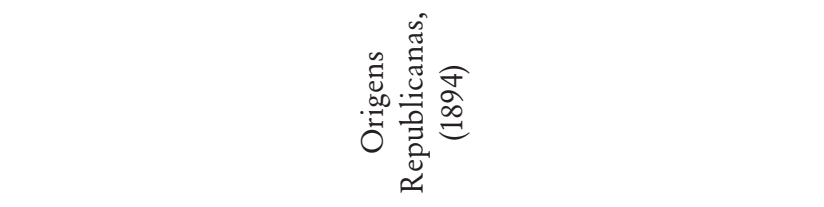 \\
\hline 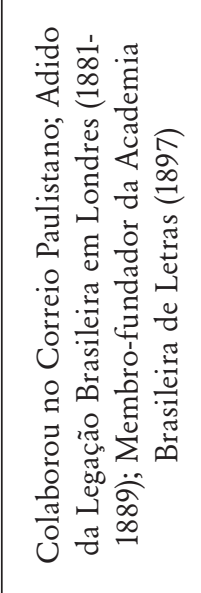 & 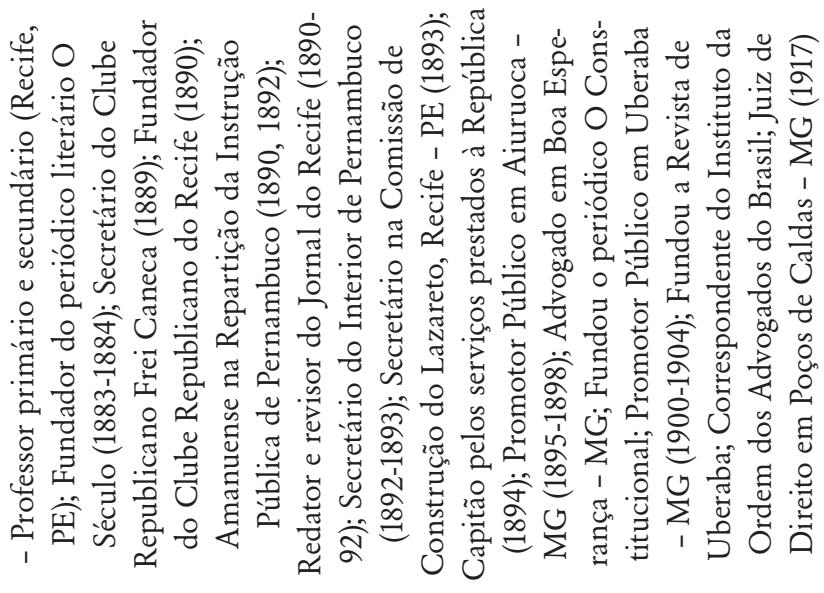 \\
\hline 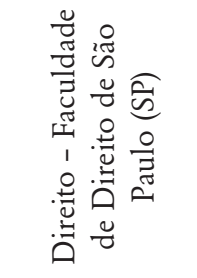 & 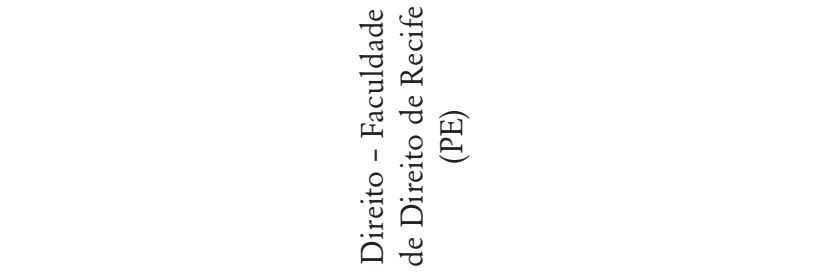 \\
\hline 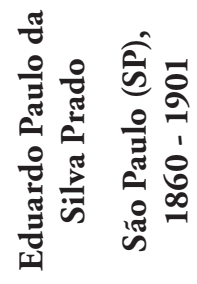 & 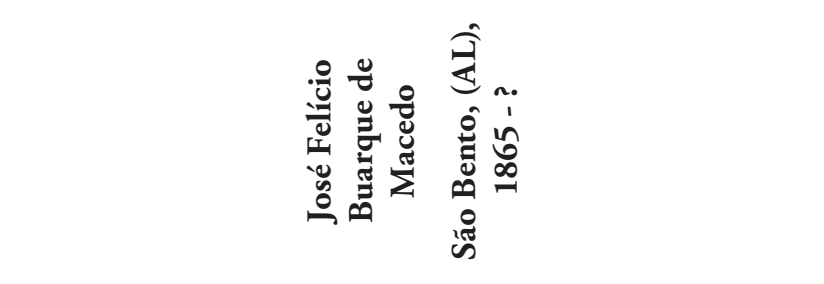 \\
\hline
\end{tabular}

n

$\vdots$ 
As origens e o significado...

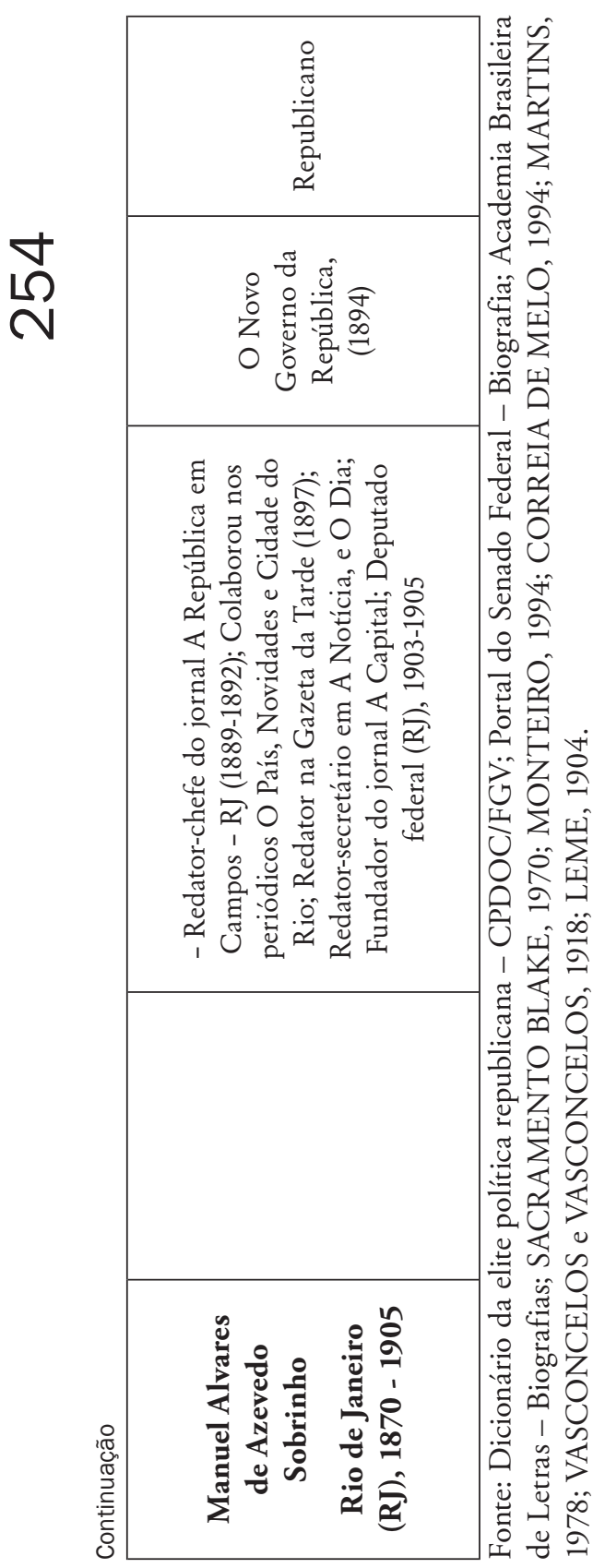

Anos 90, Porto Alegre, v. 23, n. 43, p. 235-266, jul. 2016 
Cristiano Benedito Ottoni advém de uma família ligada à colonização da região nordeste de Minas Gerais. Seu bisavô, Emmanuel Antão Ottoni, desembarcou em São Paulo em 1727, dirigindo-se posteriormente para o Rio de Janeiro, de onde seu filho, Manuel Vieira Ottoni, parte para Vila Príncipe, em Minas Gerais, com vistas à ocupação de um cargo na Casa Real de Fundição. O pai de Cristiano Ottoni, Jorge Benedicto Ottoni, filho de Manuel, atua na mineração e no comércio, ocupando sucessivamente cargos na política local em Vila Príncipe. Seu irmão mais velho, Teófilo Benedito Ottoni (18071869), formou-se na Academia Militar (RJ), exercendo os cargos de vereador em Vila Príncipe, deputado provincial, deputado geral e senador por Minas Gerais. Foi líder da Revolução Liberal em Minas Gerais, sendo preso e, em seguida, anistiado pelo imperador Pedro II. Cristiano Ottoni segue os passos do irmáo, formando-se na Academia Militar (RJ) e chegando a capitáo-tenente da Armada, foi professor da Escola da Marinha e da Academia de Belas Artes, ambas no Rio de Janeiro. Em consonância com os investimentos familiares - seu irmão, Teófilo, fundou a Companhia do Macuri, investindo na colonização, navegação e exploraçáo de estradas de ferro -, assumiu o cargo de diretor da Estrada de Ferro Pedro II. Além disso, foi deputado geral por Minas Gerais entre 1848 e 1868, alcançando o senado em 1869, pela província do Espírito Santo. Seu irmão, Teófilo, encabeçara a lista tríplice do senado por cinco vezes consecutivas, sempre preterido na escolha real, alcançando o posto somente em 1864 . O bloqueio às pretensôes do irmão ao cargo senatorial é referido como um exemplo da prática imperial de "anulação sistemática dos homens notáveis" (OTTONI, 1890, p. 114). Participando da cisão interna ao Partido Liberal e da fundação do Clube Radical, Cristiano Ottoni foi signatário do Manifesto Republicano, em 1870, embora afirme não ser da "militância política" republicana (OTTONI, 1890, p. 75). Situados em facçôes opostas no interior do Partido Liberal, Ottoni avalia o "último ministério", presidido por Ouro Preto, como "estreitamente relacionado com a queda da Monarquia” (OTTONI, 1890, p. 90-91). Em termos gerais, o conhecimento prático da política permite que Ottoni tome uma posição ambivalente no período de organização formal do Partido Republicano, tentando, inclusive, embaraçar a "[...] manifestaçáo de 1870". Como náo obteve sucesso, manteve-se 
próximo, "[...] obedecendo a consideraçôes que no momento [lhe] ocorreram". Ao ficar com um pé em cada lado, ou seja, ocupando uma cadeira no senado imperial e não rompendo com o movimento republicano, criou as condiçôes de possibilidade para fugir ao bloqueio das posiçóes políticas após a instauração da República. Assim, investe na reprodução do cargo ocupado na Monarquia, elegendo-se senador por Minas Gerais até 1896.

A abertura de possibilidades derivadas da extensão dos níveis de inserção e do engajamento na "propaganda republicana" tem efeitos significativos na trajetória de José Felício Buarque de Macedo, cuja carreira pode ser caracterizada como um "produto" da instauração da República. Descendente de uma família de comerciantes portugueses instalados em Alagoas, as informaçóes imprecisas tornam a definição completa de suas origens sociais mais difíceis. No entanto, ao que tudo indica, a família tenha sido proprietária, no início do século XIX, de um engenho de açúcar. Com a decadência econômica da região e a impossibilidade de manutençáo da propriedade, desestruturada com a partilha de herança, a família reconverte os investimentos para um pequeno comércio de gêneros alimentícios no interior de Alagoas (HOLANDA, 2007, p. 619-639). Sendo o segundo de seis irmãos, sobre os quais não se dispóem de informaçóes, Felício Buarque faz as primeiras letras sob os auspícios da família, em Magagogy (AL), partindo para Recife (PE), onde ingressa no Colégio de Artes. As dificuldades financeiras são supridas pelo auxílio de "uma madrinha" residente em Pernambuco, a qual o acolhe e o ajuda com o custeio dos estudos. Exerce a atividade de professor primário, ainda durante os preparatórios para a Faculdade de Direito do Recife (PE), e obtém o diploma de bacharel em direito em 1894. Ao formar-se, contava 29 anos, idade que caracteriza um percurso mais longo, o que normalmente representa origens sociais mais baixas em comparação com aqueles que obtinham as mesmas espécies de credenciais nesse período. Ainda em Recife (PE), atua no jornalismo político-estudantil, participa da fundação e direção de clubes republicanos e escreve como correspondente para o jornal República Brasileira, publicado no Rio de Janeiro, cujo diretor era José Cândido Teixeira. Com a instauração da República, galga seus primeiros cargos públicos a partir de 1890. No conjunto de sua trajetória, a militância republicana é determinante para 
a conquista de posiçôes que lhe permitem alguma "independência" econômica. Inserido diretamente nas disputas faccionais que cindem a política pernambucana, Felício Buarque é exonerado do cargo de amanuense com a subida do Barão de Lucena ao comando executivo estadual, sendo posteriormente reintegrado com a recomposição da Junta Governativa ${ }^{6}$.

Ao formar-se bacharel em direito, no contexto de eclosão de revoltas contra o governo republicano, Felício Buarque transfere-se para a cidade do Rio de Janeiro, onde engaja-se na defesa de Floriano Peixoto, durante a Revolta da Armada. O efeito imediato da adesão ao conflito é a conquista das honras de Capitão do Exército por "serviços prestados à República" 7 . Ainda em 1894, publica seu manifesto em defesa do regime republicano: Origens Republicanas. Elaborado em "refutação ao livro do Sr. Dr. Afonso Celso, O Imperador no Exílio", o opúsculo pretende-se um “[...] protesto, um grito de alarma de são brasileirismo, um brado de entusiasmo para um futuro melhor" (BUARQUE, 1894, capa). A multiplicação de frentes de atuação, associadas à posse de um título de ensino superior, permite o ingresso na magistratura, o que o leva ao deslocamento para Minas Gerais, durante o governo de Bias Fortes. Naquele estado, exerce a advocacia e o jornalismo, residindo, por fim, em Poços de Caldas (MG), onde é nomeado juiz de direito. O alcance de suas redes está fundado, principalmente, na militância constituída durante a "propaganda republicana" e a inserção em círculos de empregos públicos. No entanto, as relaçóes entre origens e possibilidades de carreira implicam um teto, representado pelo cargo de juiz de direito e pela inserçáo como correspondente no Instituto dos Advogados do Brasil. Sua própria produção cultural, amplamente fundada na publicação de artigos jornalísticos de cunho político, tende a um alcance limitado. Mesmo aquela que pode ser considerada sua obra mais expressiva, cuja aceitação poderia inseri-lo no debate político-ideológico mais significativo de meados dos anos de 1890, é, ao que tudo indica, desconsiderada por seu adversário imediato e proclamado: Afonso Celso de Assis Figueiredo Junior ${ }^{8}$. Sendo assim, se a instauração do regime republicano garantiu-lhe possibilidades de acesso às retribuiçóes decorrentes do engajamento na contestação da Monarquia, o deslocamento de trajetória é limitado por suas 
origens sociais, mas também pelos trunfos passíveis de serem acionados e transformados em cargos.

Ao contrário de seu contemporâneo, Afonso Celso de Assis Figueiredo Junior parte de outras condiçôes sociais, tornando o engajamento e a afirmação de "causas" algo secundário em sua trajetória. Nascido em uma família extensa, formada por laços matrimoniais entre fraçôes sociais que ocupavam, desde o período colonial, posiçôes centrais no controle político e econômico do país, Afonso Celso é educado por preceptores em sua residência, na cidade do Rio de Janeiro, e realiza "viagens de estudos" a Europa durante a sua juventude. Filho de Afonso Celso de Assis Figueiredo e de Francisca de Paula Martins Toledo, suas origens sociais são duplamente potencializadoras. Seu pai é proveniente de uma família destinatária de mercês imperiais e instalada na regiâo das Minas Gerais, tendo ocupado vários cargos políticos em nível provincial, tais como o de Chefe de Polícia, Inspetor da Tesouraria Provincial, Procurador da Fazenda, Deputado Provincial e Deputado Geral por Minas Gerais. Tendo ocupado diversas pastas como Ministro do Império, chegou ao cargo vitalício de Senador, galgando uma posiçáo no Conselho de Estado e, por fim, presidindo o Conselho de Ministros (1889). Titular das honras de Visconde de Ouro Preto, o pai de Afonso Celso é caracterizado como um dos políticos mais importantes do Segundo Reinado. No que se refere às origens maternas, Afonso Celso descendia dos Toledo, grupo familiar instalado em São Paulo desde o século XVIII. Seu avô materno, Joaquim Floriano de Toledo, era descendente de militares, grande proprietário rural, Coronel da Guarda Nacional e "secretário particular de Dom Pedro I" 9 . Exerceu diversos cargos públicos, sendo Deputado Provincial por várias legislaturas e assumindo por seis vezes a Presidência da Província de São Paulo.

Em um universo familiar altamente integrado às estruturas de poder da Monarquia, Afonso Celso adquiriu permissáo para matricular-se na Faculdade de Direito de São Paulo sem a idade mínima exigida, a saber, quinze anos. Logo no início do ensino superior, investe em suas primeiras publicaçôes literárias com o livro Prelúdios (1876), coleção de anotações e poesias elaboradas durante a adolescência. Obtém o grau de bacharel em direito em 1880 e, no ano seguinte, o grau de doutor. Tendo à sua disposiçãa um conjunto 
de redes de relaçóes derivadas do grupo familiar e as credenciais que legitimam as pretensóes culturais e políticas, ingressa diretamente no cargo Deputado Geral por Minas Gerais. Inserido pelas mãos de seu pai, que lhe "[...] abriu as portas dessa carreira [...]" (AFONSO CELSO, 1998 [1898], p. 12), permanece no exercício do cargo legislativo até a queda da Monarquia. Após a proclamação da República, acompanha a família real no exílio, circulando por países da Europa e frequentando os círculos da "alta sociedade", principalmente em Portugal e na França (AFONSO CELSO, 1950 [1893]). Autoexilado, mantém suas publicaçôes no Jornal do Brasil, do qual era sócio-proprietário ao lado da família Mendes de Almeida. Durante os anos na Europa, na companhia da família real, escreveu seu livro-manifesto contra o regime instalado no Brasil em 1889: O Imperador no Exílio (1893). Organizado em duas partes: a primeira pretende apresentar o reconhecimento que as "grandes personalidades" brasileiras davam ao Imperador deposto pelo "golpe militar", mostrando a "injustiça" de tal ato e do atual estado de difamação de sua imagem por parte dos republicanos instalados no poder; a segunda traz uma biografia de Dom Pedro II, cujo objetivo é resgatar sua personalidade liberal e democrática. A publicação do livro rendeu-lhe as honras de sócio-efetivo do Instituto Histórico Geográfico Brasileiro (IHGB), além disso, a obra foi adotada, reproduzida e distribuída por grupos monarquistas no Rio de Janeiro e em São Paulo.

Retornando ao Brasil com sua família, Afonso Celso afastase da política e investe no universo cultural. Publica vários livros contendo memórias de sua circulaçáo no interior das estruturas de poder, uma biografia de seu pai e outros escritos literários de gêneros variados. Mantém sua coluna de comentários políticos, econômicos, sociais e literários no Jornal do Brasil, e ingressa na recém-fundada Faculdade Livre de Ciências Jurídicas e Sociais do Rio de Janeiro, na qual veio a ocupar a cátedra de Economia Política e, posteriormente, a diretoria da instituição. Após a morte do Barâo do Rio Branco, é "aclamado" como presidente perpétuo do IHGB. Com a nacionalização das faculdades livres de direito e a criação da Universidade do Rio de Janeiro, mantem-se como professor, sendo nomeado reitor dessa instituição nos anos 1930. No conjunto de investimentos e redes de relaçôes que lhe estáo disponíveis, insere-se no movimento 
de fundação da Academia Brasileira de Letras (ABL), em 1898, da qual foi presidente em duas ocasióes. A reconversão dos recursos econômicos e políticos herdados e conquistados durante o Império possibilitaram a ocupação de posiçóes centrais nas redes de recrutamento para instituiçôes de consagração social e intelectual, além da obtenção de um leque de títulos honoríficos, ostentados por sua biografia como signos de excelência social e de trajetória de sucesso. A relativa independência econômica possibilitou a vivência da cultura como "estilo de vida", atuando assiduamente nas reuniōes da ABL ou do IHGB. Da mesma forma, o universo de origem e os espaços de inserção facilitam a ocupação de cargos públicos em diferentes momentos políticos do país. Nesse quadro de referência, a socialização através da militância é secundária, assim como a afirmação de posições políticas a partir de estratégias de publicação ou do jornalismo. Seus escritos são apresentados muito mais como memórias de outros tempos, ou como "lampejos" de patriotismo, do que propriamente como textos de afirmação ideológica ou tomadas de posição.

No quadro destes confrontos entre origens sociais e tomadas de posição políticas, os efeitos de transição entre os regimes e as oportunidades abertas marcam distintamente as trajetórias e os princípios ideológicos proclamados. A representação vigente de que o regime republicano representava a "influência das classes terciárias na política" (BUARQUE, 1894, p. 33) e a emergência de uma "nova orientação política" decorrente do "advento das mais recentes camadas sociais" (AFONSO CELSO, 1998 [1898], p. 130), constitui um esquema de visão relativamente compartilhado. Portanto, engloba as representaçóes que os agentes que tomam parte no processo fazem de si mesmos e do momento histórico no qual estão inseridos. Além disso, a definição de que se trata de um contexto sócio-histórico no qual estão em confronto "competências" ancoradas em legitimidades distintas - lógica eleitoral, títulos escolares -, contribui decisivamente para a crença no "mérito" como ponto de chegada e princípio de justificação dos pontos que marcam as trajetórias. Discurso de normatização e de definição dos caminhos de sucesso, a "moral social" inscrita nas representações acerca da "filosofia meritocrática" é historicamente situada, englobando distintas representaçóes acerca dos pontos de partida, dos recursos exigidos e dos modos de acesso aos cargos. 


\section{Consideraçóes finais}

Em grande medida, ao centrar-se no exame dos sentidos atribuídos às mudanças em curso no Brasil de fins do XIX, a partir dos relatos que denotam as próprias posiçôes dos emissários do discurso, tornam-se evidentes as transformaçóes dos princípios legítimos de legitimação e da "simbologia da excelência" (BOURDIEU; BOLTANSK; SAINT-MARTIN, 1973, p. 80). É justamente isso que interessa como uma dimensão continuamente negligenciada pelos estudos sobre os efeitos da mudança de regime para a recomposição de "elites": considerar em que medida os princípios reivindicados têm condiçôes de se objetivar em mecanismos de seleção e recrutamento, colocando-os em relaçáo com a visão que os agentes produzem de si mesmos e do universo no qual se movem. No entanto, isso só pode ser apreendido pela combinação entre os esquemas de percepção que orientam as práticas de época, embasam as tomadas de posição e fundamentam as categorias de classificação de si e dos outros; e os recursos e estratégias de açáo que estão na base das condiçôes objetivas de acesso aos cargos e posiçóes visadas. O esquecimento das necessidades de se romper com a oposição entre "objetivismo" e "subjetivismo", tende a contribuir para a legitimação da visão que os diferentes grupos sociais ou agentes elaboram sobre si mesmos, sobre seus adversários e sobre os conflitos nos quais se inserem.

Nesse sentido, o conjunto de representaçóes acionadas como formas de reconstruçáo do passado e a caracterizaçáo do presente colocam em pauta os diferentes critérios de excelência social e os modos legítimos de acesso aos cargos e honrarias, acionando um sistema de classificaçóes que operam pela homologia entre um espaço formado pelos regimes em confronto (Monarquia versus República), e suas diferentes modalidades de adjetivação: "tradicional" versus "moderno", "favoritismo" versus "impessoalidade", "conservação" versus "mobilidade", "privilégios" versus "competência". No entanto, como procurou-se demostrar, as possibilidades efetivas de inscriçáo dos agentes nestes pares de oposição são variáveis, dependendo do cabedal de recursos sustentados objetivamente pelas biografias individuais e, obviamente, pelas redes de relaçóes herdadas e/ou adquiridas que embasam as chances de sucesso. É assim que determinados agentes transitam de 
modo seguro entre os discursos de legitimação relacionados aos distintos momentos históricos em pauta. Colocando de outro modo, ao possuírem as redes que sustentam o favoritismo e, ao mesmo tempo, os títulos que constituem a base formal para a reivindicação da competência, valem-se desses diferentes recursos em situaçôes específicas. Isso configura uma espécie de formalismo, o qual pode ser definido como um apego específico aos títulos formais ou à biografia oficial, e posteriormente sua associação direta aos cargos ocupados e agraciaçôes. Dessa forma, o questionamento sobre as condições de produção e imposição das versôes oficiais sobre determinados fatos ou agentes ficam em segundo plano, prevalecendo o raciocínio tautológico.

Ao contrário, o peso de determinados recursos e os efeitos de trajetória decorrentes da transição entre a Monarquia e a República são dependentes das bases sociais sobre as quais se assentam as pretensôes de carreira e suas condiçóes de efetivação. A militância via jornalismo político, por exemplo, constitui-se como uma estratégia de investimento diferencialmente acionada de acordo com as posiçóes de origem. No entanto, independentemente das posiçóes ideológicas proclamadas ou atribuídas aos agentes em confronto, a ocupação de cargos e os deslocamentos nas carreiras estão diretamente escorados em lógicas de cooptação, clientelismo e patronagem. Sendo assim, o que se transforma de modo mais explícito são os modos de justificação das escolhas e as definiçóoes de mérito, em grande parte fundadas na posse formal de títulos escolares ou na noção de reconhecimento pelos pares. Além disso, os esforços dos contemporâneos em definir a República como um movimento das "novas classes sociais" emergentes, leva ao processo contínuo de "condenação das heranças" e das "posiçôes privilegiadas", elementos que são incorporados pelos emissores de discursos sobre si mesmos e sobre os outros. É a partir disso que Afonso Celso (1998 [1898]) vai afirmar que "[...] todos eram pobres [...]" entre os deputados gerais e ministros do império, e que a "[...] política até então nunca enriquecera ninguém no Brasil" (AFONSO CELSO, 1998, p. 28). O mais importante neste modo de reconstrução do passado e de seu próprio trajeto biográfico não é verificar sua veracidade, mas apreender o que ele informa sobre a reprodução das desigualdades sociais e sua legitimação. Portanto, se a instauração do regime republicano representou a realização das 
pretensôes de controle das eleiçôes estaduais pelos chefes locais, com resultados significativos para a multiplicação dos níveis de barganha, a diversificação das modalidades de recrutamento e de acesso aos cargos em concorrência, tais processos não podem ser pensados sem a consideração de duas variáveis: 1. as representaçóes acerca dos atributos necessários para a ocupação dos diferentes cargos em disputa; 2. as condiçóes objetivas de acesso a esses atributos legítimos em um contexto de elevada desigualdade social.

\section{THE ORIGINS AND THE REPUBLICAN REGIME'S SIGNIFICANCE: INTERPRETATIONS IN DISPUTE}

Abstract: This article intents to show the problem of relationships between social agents, political positions, and the modes of significations of the events that marked the transition between political regimes in Brazil at the end of the ${ }^{19 t h}$ Century. From a set of situated symbolic productions, the analysis focuses on the examination of the assigned senses and the explanations used for the falling of the monarchic regime and the rising of republicanism. The main goal is to learn the representations that underlie the legitimate ways to the claiming of access to the opened positions and opportunities by the new regime.

Keywords: Monarchy. Republic. Principles of Legitimation.

\section{Notas}

${ }^{1} \mathrm{O}$ fim da escravidão é proclamado como exigência civilizatória, em oposição aos interesses econômicos (OTTONI, 1890, p. 52).

${ }^{2}$ Para os efeitos da propaganda organizada em torno do jornalismo político, ver Boeher (1954).

${ }^{3}$ Ver, particularmente, Sales (1885) e Assis Brasil (1881), consideradas as principais obras de "doutrinação" republicana, obtiveram um alcance significativo para o período. Distribuídas pelo Partido Republicano de São Paulo, a primeira alcançou doze mil exemplares, a segunda foi reeditada seis vezes, até 1889 (ALONSO, 2002, p. 223).

${ }^{4}$ Ver, também, Alonso (2002, p. 183).

${ }^{5}$ Para os conflitos políticos em Pernambuco, ver Levine (1980).

${ }^{6}$ Diário Oficial da União, 9 de novembro de 1894, p. 4291. 
${ }^{7}$ Não foi encontrada nenhuma resposta ao livro de Felício Buarque, elaborada por parte de seu oponente proclamado, Afonso Celso Junior.

${ }^{8}$ Biografia de Pedro Manuel de Toledo, neto de Joaquim Floriano de Toledo. Verbete no Dicionário da Elite Política Republicana-CPDOC / FGV.

\section{Referências}

ACADEMIA BRASILEIRAS DE LETRAS - Biografias. Disponível em: http:// www.academia.org.br/academicos/membros. Acesso em: jan. 2015.

AFONSO CELSO. O Imperador no exílio. Rio de Janeiro: Livraria Francisco Alves, 1950 [1893].

. Oito anos de parlamento. Brasília: Senado Federal, 1998 [1898].

ALONSO, Ângela. Idéias em movimento: a geração de 1870 e a crise do Brasil Império. São Paulo: Paz e Terra, 2002.

. Apropriação de ideias no Segundo Reinado. In: SALLES, Ricardo;

GRINBERG, Keila (Orgs.). O Brasil Imperial, v. III (1870-1889). Rio de Janeiro: Civilização Brasileira, 2009.

ANAIS DO SENADO DO IMPÉRIO DO BRASIL, 1830-1888. Disponível em: http://www.senado.leg.br/publicacoes/anais/asp/IP_AnaisImperio.asp. Acesso em: jan. 2015.

ASSIS BRASIL, Joaquim Francisco de. A república federal. Rio de Janeiro: Leuzinger \& Filhos, 1881.

AZEVEDO, Manuel Álvares. O novo governo da República. Rio de Janeiro: Imprensa Nacional, 1894.

BOCAIUVA, Quintino. A segunda phase. Discurso a Confederação Abolicionista proferido em 03 de abril de 1887. Rio de Janeiro: Typographia Central de Evaristo da Costa, 1887.

. Prefácio. In: SUETÔNIO (VIANNA, Antônio Ferreira). O antigo regimen: homens e coisas. Rio de Janeiro: Cunha \& Irmão, 1896.

BOEHRER, George. Da monarquia à república: história do partido republicano do Brasil (1870-1889). Rio de Janeiro: Serviço de Documento do MEC, 1954.

BONAVIDES, Paulo; AMARAL, Roberto. Textos politicos da história do Brasil: Primeira República (1889-1930). v. III. Brasília: Senado Federal, 2002. 
BOURDIEU, Pierre; BOLTANSKI, Luc; SAINT-MARTIN, Monique. Les stratégies de reconversion: les classes sociales et le système d'enseignement. Social Science Information, v. 12. n. 5, p. 61-113, 1973.

BOURDIEU, Pierre. O Poder simbólico. Rio de Janeiro: Bertrand Brasil, 2007.

BUARQUE, José Felício. Origens republicanas: estudos de gênese política, em refutação ao livro do Sr. Afonso Celso, O Imperador no Exílio. Recife: Francisco Soares Quintas, 1894.

CAMPOS SALLES, Manuel Ferraz. Da propaganda à presidência. São Paulo, 1908. CORREIA DE MELLO, Luís. Subsidios para um dicionário dos intelectuais rio-grandenses. São Paulo: Civilização Brasileira, 1944.

COSTA, Emília Viotti da. Da monarquia à República: momentos decisivos. São Paulo: Editora da UNESP, 1999.

DICIONÁRIO DA ELITE POLÍTICA REPUBLICANA - CPDOC/FGV. Disponível em: http://cpdoc.fgv.br/dicionario-primeira-republica. Acesso em: 23 maio 2013. FERREIRA, Marieta M.; GOMES, Ângela de Castro. Primeira República: um balanço historiográfico. Estudos históricos - Rio de Janeiro, v. 2, n. 4, 1989, p. 244-280.

HOLANDA, Bartolomeu Buarque. Buarque: uma família brasileira - ensaio histórico-genealógico. Rio de Janeiro: Casa da Palavra, 2007.

LEME, Luiz Gonzaga da Silva. Genealogia paulista. Vol. IV. São Paulo: Duprat\& Comp., 1904.

LEVINE, Robert K. A velha usina: Pernambuco na federação brasileira, 1889-1937. São Paulo: Paz e Terra, 1980.

MANIFESTO DO PARTIDO REPUBLICANO, 1870. In: BRASILIENSE, Américo. Os programas dos partidos políticos e o segundo império. São Paulo: Jorge Seckler, 1878.

MARTINS, Ari. Escritores do Rio Grande do Sul. Porto Alegre: Editora da UFRGS, Instituto Estadual do Livro, 1978.

MONTEIRO, Norma G. Dicionário biográfico de Minas Gerais - período republicano - 1889-18991. Dois volumes. Belo Horizonte: Assembleia Legislativa do Estado de Minas Gerais, 1994.

NABUCO, Joaquim. Minha formação. Rio de Janeiro: H. Garnier, 1900.

O abolicionismo. Rio de Janeiro: Centro Edelstein de Pesquisas Sociais, 2011 [1883].

OTTONI, Christiano B. O advento da república no Brasil. Rio de Janeiro: Typographia Perseverança, 1890.

Anos 90, Porto Alegre, v. 23, n. 43, p. 235-266, jul. 2016 
OURO PRETO, Visconde. Advento da ditadura militar no Brasil. Paris: Imprimerie F. Pichon, 1891.

PATROCÍNIO, José. A campanha abolicionista. Rio de Janeiro: Fundação Biblioteca Nacional. Dep. Nacional do livro, 1996.

PORTAL DO SENADO FEDERAL - Biografias. Disponível em: http://www25. senado.leg.br/web/senadores. Acesso em: nov. 2013.

PRADO, Eduardo. A ilusão americana. Brasília: Senado Federal, 2003 [1893]

SACRAMENTO BLAKE, A.V.A Dicionário bibliográfico brasileiro. Sete volumes. Rio de Janeiro: Conselho Federal de Cultura, 1970 [1883-1902].

SALLES, Alberto. Politica republicana. Rio de Janeiro: Leuzinger \& Filhos, 1882. . Catecismo republicano, 1885. In. VITA, Luiz Washington. Alberto Sales, ideólogo da República. São Paulo: Companhia Editora Nacional, 1965.

STEIN, Stanley. A historiografia no Brasil (1808-1889). Revista de História. São Paulo, v. 29, 1964, p. 81-131.

SUETÔNIO (VIANNA, Antônio Ferreira). O antigo regimen: homens e coisas. Rio de Janeiro: Cunha \& Irmão, 1896.

TAVARES BASTOS, Aureliano. A província: estudo sobre a descentralização no Brasil. Rio de Janeiro: H. Garnier, 1870.

VASCONCELOS, Barão; VASCONCELOS, Barão Smith. Arquivo nobiliárquico brasileiro. Suíça - Lausanne: Imprimerie La Concorde, 1918.

VIANNA, Oliveira. O ocaso do Império. Brasília: Senado Federal - Conselho Editorial, 2004 [1925].

WEISZ, George. L'idéologie républicaine et las sciences sociales: Les durkheimiens et la chaire d'histoire d'économie sociale à la Sorbonne. Revue Française de Sociologie, v. 20 n. 1, 1979, p. 83-112.

Recebido em: 20/ 12/ 2015

Aprovado em: 18/ 03/ 2016 